\title{
Modern Chinese National-Cultural Identity in the Context of Globalization
}

L'identité culturelle et nationale chinoise moderne dans le contexte de la mondialisation

\section{Yujun WU}

\section{(2) OpenEdition}

\section{Journals}

Édition électronique

URL : http://journals.openedition.org/transtexts/456

DOI : $10.4000 /$ transtexts.456

ISSN : 2105-2549

Éditeur

Gregory B. Lee

Référence électronique

Yujun WU, « Modern Chinese National-Cultural Identity in the Context of Globalization », Transtext(e)s Transcultures 跨文本跨文化 [En ligne], 7 | 2012, mis en ligne le 02 décembre 2012, consulté le 10 décembre 2020. URL : http://journals.openedition.org/transtexts/456 ; DOI : https://doi.org/10.4000/ transtexts.456 


\section{Transtext(e)s Transcultures 跨文本跨 文化}

Journal of Global Cultural Studies

7 | 2012 :

Transcultural Identity and Circulation of Imaginaries

Transcultural Identity and Circulation of Imaginaries

\section{Modern Chinese National- Cultural Identity in the Context of Globalization}

L'identité culturelle et nationale chinoise moderne dans le contexte de la mondialisation

YUJUN WU

\section{Résumés}

\section{English Français}

When modern China first entered the progression of globalization, it was faced with a strong "other" in the Western developed countries. The country's backwardness on economic, political and military levels spawned a predicament for modern Chinese national-cultural identity. On the one hand, to stand out in the world, it must seek modernity; on the other hand, to maintain the nation's independent traits, it must be alert to the dangers of a Western-centric modernity. China has a conflictual relationship with globalization dominated by Western countries and with its own cultural tradition. This double bind, with conflicts between the self and the other, on the one hand, and tradition and modernity, on the other hand, has contributed to the formation of the ambivalent characteristics of modern Chinese national-cultural identity.

Quand la Chine moderne entra pour la première fois dans la mondialisation, elle se retrouva face à un puissant " autre » dans les pays développés occidentaux. Le retard économique, politique et militaire du pays engendra une situation difficile pour l'identité culturelle nationale chinoise moderne. D’une part, pour s'affirmer dans le monde, la Chine devait être en quête de modernité ; d'autre part, pour maintenir les traits caractéristiques de la nation, elle devait être alerte vis-à-vis des dangers d'une modernité centrée sur l'Occident.

La Chine a une relation conflictuelle non seulement avec une mondialisation dominée 
par les pays occidentaux mais aussi avec sa propre tradition culturelle. Cette situation doublement difficile, due au conflit entre le moi et l'autre d'une part, et entre la tradition et la modernité d'autre part, a contribué à la formation des caractéristiques ambivalentes de l'identité culturelle nationale chinoise moderne.

\section{Texte intégral}

The process of globalization is one in which various powers play games with one another. Countries in powerful positions exert influence on underdeveloped countries through their own economic, political and military advantages, and they attempt to import the less powerful countries into their own developing systems. Thus, the process of globalization is simultaneously a process of manipulation and power in which the mainstream, socially dominant cultural mode becomes the template or the goal to which others must strive. This process of identifying the self with the other in the process of globalization has had a significant impact on modern Chinese national-cultural identity. The nexus between the self and the other has accompanied the entire process of constructing modern Chinese national-cultural identity.

\section{The crisis of national-cultural identity in modern China}

Identity is a process of recognition. In a comparison between the self and the other, the former attempts to determine the similarities and differences between them before affirming "Who I am", or the identity of the self. The formation of identity should take the other's views as the premise, and the definition of the self always distinguishes the other's value, characteristics and lifestyle.

$3 \quad$ The other is a particular being. On the one hand, it is different from the self; on the other hand, the self cannot become what it is and cannot attain self-consciousness or a sense of self-identity unless it understands the other. Hence, the other is another self that is closely related to the self, and it constitutes a mirror for the self to review itself. By virtue of the mirror of the other, the self can better recognize its own image.

4 Although the other's role as a mirror to review the self is important, the role of the other is accepted by the self in negative sense. A powerful dimension is contained internally between the self and the other. Hegel's analyses with regard to the lord-bondsman relationship in his Phenomenology of Spirit have demonstrated this dimension. In Hegel's view, the emergence of the other is indispensable to the formation of self-consciousness. The comportment between the lord and bondsman is a struggle, both intending to extirpate the other party and to demonstrate their own existence. The result of the conflict is that the stronger the lord becomes, the weaker the bondsman becomes. "Since he is the power over this thing and this again is the power over the other [the bondsman], it follows that he holds the other in subjection."1 In the process of cultural communication, power games between the self and the other are embraced via a relationship that is both explicit and implicit. This is even more evident when a culture with strong economic and military backing has a 
significant influence on another party.

When the self treats the other as a dimension of difference and attempts to import it into its own orbit, the self obtains a strong sense of identity and of belonging. This is evident in the construction of the Chinese traditional national identity. Before modern times, China followed the Huaxia 华夏 idea that "those foreign to us surely have different minds", affirming its own ideal image by means of the mirror of the other of foreign tribes. According to the idea of Huaxia-centralism, the differentiation between Huaxia and foreign tribes is established not on ethnic but on cultural bases. As Confucius says in Spring and Autumn Annals, "When foreign tribes enter into the Central Plains, they will be centralized; when people of Central Plains enter into foreign tribes, they will be foreignized". That is, when people of foreign tribes enter the Central Plains, they become accustomed to the cultural conventions of Huaxia and hence become members of the Huaxia nation; in contrast, when people of the Central Plains enter remote areas and become accustomed to their cultural conventions, they also become foreigners. Whether one is a foreign tribe or Huaxia does not lie in the blood relationship but in the culture to which people are accustomed. To put it differently, the differentiation between Huaxia and foreign tribes is not pertinent to blood relationships but to culture. Huaxia is the incarnation of culture and civilization. Etymologically speaking, the two characters of Hua 华 and Xia 夏 sound similar and can interchange with each other. "Hua" originally meant flower and was later extended to "rich and bright colors" and "civilization". "Xia" is a name for a place, state or nation and is extended to "great". According to the annotations and exegeses by Kong Yingda in Zuozhuan · Dinggong the Tenth Year (左传.定公十年), "There is the greatness of rites in Central Plains, which is called Xia; there is the beauty of rich and bright colors, which is called Hua". Hua and Xia combined means great cultivation. Correspondingly, "foreign tribes" is a synonym for barbarity against culture. As noted in Liji - Quli Part A (礼记·曲礼上), "The parrot can speak, but it is forever a bird; the gorilla can speak, but it is forever a beast. Now some men obey no ritual, don't they have beast-like minds although they can speak? Therefore, the sage appears and saves people via rituals to make people know that they are different from birds and beasts thanks to following rituals". ${ }^{2}$ It was accepted that the ritual civilization of Huaxia was a unique form of civilization. Consequently, although foreign tribes did not lack their own rituals and customs, because these customs did not accord with the rituals of Huaxia and were inferior to the latter on the level of civilization, they were considered analogous to birds and beasts. Due to this palpable difference between Huaxia and foreign tribes in the sense of rituals and culture, people contended that there should be a hierarchical state between them, with Huaxia as the center and foreign tribes on the periphery. According to the idea of Huaxia-centralism, this state of "being present at Central Plains and pacifying the peripheral foreign tribes" is quite natural.

6 If the consciousness of Huaxia-culture-centralism is based on its cultural superiority to "foreign tribes", the consciousness of Huaxia-geographycentralism is a reflection of the geographical arrangement of the borderlines between Huaxia and foreign tribes on the ideological level. From the West Zhou Dynasty to the Spring and Autumn period, there were no definite geographical borderlines between Huaxia and foreign tribes, but the idea of arranging them existed. Since the War States period, particularly after the 
beginning of "worshipping the emperor and oppressing the foreign tribes" in the Spring and Autumn period, foreign tribes had either been assimilated or forced to move to remote areas. The arrangement of Huaxia at the center with foreign tribes on the periphery took shape, and the borderlines of culture and geography between Huaxia and foreign tribes became clear.

7 The demarcation between the center and the periphery, the self and the other, has had an important influence on the construction of Chinese traditional cultural identity. The continuous improvement of Confucian ethical systems, with the Three Cardinal Guides and Five Constant Virtues as the core, increasing development of the level of rituals and cultivation and the relative occlusion of social political systems and communicative modes have reinforced the sense of superiority of the "world empire". This idealized self-image and stable value order between the self and the other have largely constituted the basis of Chinese national-cultural identity.

8 However, the sense of self-superiority and the hierarchy of the center and the periphery between the self and the other have experienced significant changes in modern time. In the mid-180os, China was forcefully brought into worldwide modernization by strong Western firepower. At that time, China's development faced a strong "other": Western powers. This external "other" has exerted a strong influence on modern Chinese national identity. Previously, the relatively strong economic, political and military powers of China enabled the "world empire" to command others with strong manipulative power, intending to guide others to its own significance of existence and standard of value. Its failure in the Opium War presented a challenge to Huaxia-centralism at different levels.

First, the weakening of Huaxia-geography-centralism. After the Opium War, geographical investigations became important work. Along with the publication of a number of Western geographical works, the idea of a central "world empire" was challenged. Lin Zexu, Wei Yuan and $\mathrm{Xu}$ Jiyu et al. produced a great deal of work on this subject. Lin Zexu is known as "the first man who opened his eyes to view the world" in modern China. In 1839, he organized people to translate Hugh Murray's The Encyclopedia of Geography, published in London in 1836, into Records of Four Continents. This book introduced new knowledge about the continents and played an important enlightening role in modern China's "heading for the world". In 1842, Wei Yuan published Records of World Geography, which provided detailed introductions to the histories and geographies of five continents and many countries in addition to a holistic map of the globe and 75 maps of each continent with very clear borderlines. In 1848, Xu Jiyu published Brief Records of the Globe, which introduced, in relatively complete fashion, a general picture of the earth, the geography, history and status quo of the four continents of Asia, Europe, Africa and America, and the fundamental conditions of the Pacific Ocean, Atlantic Ocean, Indian Ocean and the far south. These works described the world in a relatively objective way. In this way, the fairytale that China was located at "the center of the world" was shattered, and the same held true for the delusion of the "world empire".

10 Second, there was an emphasis on implementing value. Before the Opium War, in the mind of the Chinese people, the strong Western firepower was not commendable; it was diabolical and wicked. China's failure in the Opium War led to an attack on the literati and officialdom, forcing them to reexamine 
Western sciences and technologies. Of these views, the perspective of Wei Yuan, to "follow foreign advanced techniques to address the foreigners", was the most famous. This concept refers to learning from foreigners about their advanced military techniques to resist their aggression. Wei Yuan contended, "There are three advanced techniques of the foreigners: the first is warships, the second is firearms, and the third is the approaches of training as well as maintaining an army". He advocated buying warships and cannons from the West and stressed that the advanced industrial technologies of the West should be introduced to China so it could also produce warships and cannons. Introducing and learning from Western implements was a consistent stance of the later forces of the Westernization Movement, in which Chinese people took an active attitude toward the introduction of Western technologies and attempted to remedy, by virtue of Western science and technology, China's defects. The stress on strong military firepower demonstrates that during the confrontation with the West, the Chinese people lost their sense of self-superiority but maintained an attitude of accepting Western culture with pleasure.

11 Third, there was a disappearance of the sense of ritual superiority. As noted by previous analyses, in the mind of traditional Chinese people, Western countries and peripheral states were nothing other than foreign tribes who had no right to be on equal footing with Huaxia in terms of cultural rituals. This is why all diplomatic envoys of countries communicating with the Qing government had to perform the ritual of kneeling three times and touch their heads to the ground nine times to the emperor. However, after the second Opium War, the British and French envoys to Beijing were on equal footing with the Qing government for the first time. The establishment in 1861of the Foreign Office, the institution in charge of diplomatic affairs, indicates that in Sina-foreign communication, Chinese rituals lost their privilege. Along with the deepening of the semicolonial and semifeudal proceedings of Chinese society, in the mind of the so-called "foreign tribes", Chinese rituals no longer had superiority, and they lost the qualification of being on equal footing with them. Like other colonies or semicolonies in the world, China as an object conquered by the West was excluded from the group of civilized countries and became a non-civilized country yet to be cultivated.

Fourth, there were criticisms regarding the political systems. After the Opium War, pressure for social reform in China increased, but the incipient innovations remained at the implementation level from which the Westernization Movement started. The failure of the Sino-Japanese War of 1894-1895 indicated that simply relying on reform at the level of implementation without performing in-depth innovations of systems would not lead China out of the morass. The Hundred-Day Reform Movement, the New Deal of the Qing government and the capitalism revolution led by Sun Zhongshan were innovations or revolutions directed toward the old political systems. The constitutional monarchy intended by the Hundred-Day Reform and the New Deal and the capitalism republic intended by the capitalism revolution both used Western political systems as their templates. The Western other, the original object of mockery, now became an object of learning. Within only a few decades, from the 1840 os to the beginning of the 2oth century, significant changes occurred in China in relation to the value order between the self (China) and the other (the West). 

predicament and was vulnerable to the external challenges from the West. An identity crisis began to occur, and it increased with China's successive failures in Sino-foreign confrontations.

\section{Two approaches to resolving the crisis of cultural identity}

China's confrontation with the Western other has damaged Chinese traditional narration and the ideal self-image of the traditional culture. The recovery of one's self-image depends on the self reshaping a holistic story of itself that not only can renew the subjective position of the self but also can guide it to realize the story. However, the construction of this ideal self-narration is not an easy task. The developing style of Chinese modernization makes the shaping of China's self-image a complicated and difficult process. The development of Chinese modern society differs from the West in its extrinsic modernization. China's modernity is faced with the problem of tradition vs. the present as well as the East vs. the West, the self and the other. Furthermore, this matter is complicated by the fact that the two problems often interrelate and constitute the common traits demonstrated by all under-developed countries seeking modernity in the context of globalization.

In the course of globalization, modernity, originating from the West and with a "West-centralist" approach, intended to incorporate China into capitalism by its own economic and military superiority and to reform China through its own values. Faced with this situation, modern China demonstrated an extraordinarily ambivalent state of mind and comportment. On the one hand, the modernity represented by the strong external other seems to be irresistible to any country heading toward modernization; on the other hand, to maintain its particular value of existence, China cannot relinquish its traditional cultural and political values in favor of identity. Consequently, the conflict between homogenization and diversification between the self and the other led to great conflicts.

\section{Conservatism}

To resolve the loss of a conventional goal of identity, the view of the "Chinese body and Western function" in terms of the construction of a national-cultural identity emerged. Zhang Zhidong contended, "Chinese learning is internal whereas Western learning is external; Chinese learning manipulates body and mind whereas Western learning manages world affairs". Undoubtedly, the view of the "Chinese body and Western function" inherits the parlance of implementation in Chinese traditional culture; that is, "that which is superior to the form is called Dao, that which is inferior to the form is called implement". The concept of the "Chinese body and Western function" originates from the intrusion of Western culture into Chinese culture at the 
level of implement but also results from the internal inertia during changes to Chinese traditional society. The function of this view is as follows: "It offers the possibility to the reformation of tending to merits and avoiding faults, and of seeking quick success and instant benefits on implement level, but, insofar as the sign of traditional national identity is concerned, it also contains protective function". ${ }^{3}$ Nevertheless, the "Chinese body and Western function" embraces its own logic aporia: culture is more than an issue on the level of implement, and culture at the levels of system and ideology is more important in the cultural construction. The formation of cultural integrity demands mutual auspices between the levels.

The parlance of "body and function" inflicted heavy losses in the Sino-Japanese War of 1894-1895, when China's "body" suffered suspicion with regard to its reasonableness. Nevertheless, cultural narcissism remained, and the country attempted to display a sense of self-superiority by revealing the defects of the Western-power other. The beginning of WWI seemed to help China regain confidence and supported the resolution of the problem of Chinese national-cultural identity. Confronted with the depressed conditions of the post-war West, Gu Hongming, a cultural conservative, contended, "In fact I really believe that the people of Europe will find the solution of the great problem of civilization after this war,--here in China. There is, I say here again, an invaluable, but hitherto unsuspected asset of civilization here in China, and the asset of civilization is the real Chinaman. The real Chinaman is an asset of civilization because he has the secret of a new civilization which the people of Europe will want after this war, and the secret of that new civilization is what I have called the Religion of good citizenship". ${ }^{4}$

18 The view held by Gu Hongming was also manifested in the viewpoints of another thinker, Liang Qichao. In 1919, having suffered material as well as cultural deficiencies at home, Liang Qichao entered Europe intending to seek a path from the Western world for saving China and ensuring its survival. He witnessed the distress produced by the War and the brutal partition of China's rights in the "Paris Peace Conference". He felt that in terms of culture, the West was developed materially but underdeveloped spiritually; as a result, scientific and technological means ultimately became a weapon for mutual slaughter. In contrast, China was developed spiritually but underdeveloped materially, which resulted in the elegant state of rituals being reduced to the bullied objects of the Western powers. On this ground, in his famous Records of Thinkings and Viewings in Europe, Liang Qichao advocated that his countrymen should learn from European material culture and should consider European spiritual culture from a critical perspective. He wrote at the end of the book: "Our beloved youth! Attention! Stride ahead! At the other shore of the ocean, there are several thousands of hundreds of people who are worrying about their material bankruptcies and crying for help in a desperate way, and they are waiting for you to extricate them! Our ancestors in the heaven, the three great sages and many other predecessors are looking forward you as regards accomplishing their careers, and they are blessing you in virtue of their spirits". 5

19 This difference between Western and Eastern civilizations led Chinese civilization to its own superiority, which is manifested in the thoughts of Liang Shuming. In his theory of the three-stage human civilization, Liang Shuming reveals the superiority of Chinese civilization. From his viewpoint, Western, 
Chinese and Indian civilizations represent the three stages of human progression. Under the circumstances at that time, Western civilization represented the first stage of human civilization, which, despite being the culmination, was declining. Chinese civilization, in the second stage, remained to show its power at the time, but it represented the coming goal of the future development of human civilization. Seen in the progression of human civilization, this ostensibly inferior civilization was simply a premature one.

It can thus be observed that nationalisms with a narcissism complex attempt to shape the superiority of their own civilization, claiming that their "body" of culture is on a par with that of Western culture in terms of status or claiming the superiority of their cultural body. This view "implicitly means the superiority of the local spiritual culture but advocates in the meanwhile to make selective introductions from modern culture. The consequence contained by this formula is: the local culture hence owns the equipments by means of which modernity controls the nature and, simultaneously, contains its original superior spirit". ${ }^{6}$ However, this sense of the superiority of Chinese traditional culture conceived by conservative nationalism cannot escape the following historical fact: Chinese traditional civilization had difficulty responding effectively when confronting Western intrusions. To be sure, as seen from the morass faced by Western civilization, the value of Chinese culture cannot be ignored. However, the point lies in how to effectively settle the predicament with which China is faced.

\section{Radicalism}

With the recognition of the defects of its own traditional culture, the resolution of the problem of Chinese national identity began to proceed in the opposite direction: it changed from emphasizing the superiority of its own cultural tradition to radically criticizing it. The fact that modern China continued to fail in struggles with the West battered China's national dignity. There would be no problem to speak of without addressing the path leading China toward prosperity.

22 After the Sino-Japanese War of 1894-1895, the mood of nationalism in China increased. The strong desire to make the state powerful pushed radical nationalism onto the historical stage. This position held that there was a hierarchical difference in addition to a qualitative difference between cultures. The scientific spirit of the modern West was its main strength guiding it toward power, and the advancement of the West could be found in its scientific spirit of reason. Thus, what China lacked was this scientific spirit of reason, and the task with which China was faced was not retaining traditional culture but accepting Western culture bravely and completely, employing the scientific spirit to guide society. From the radical viewpoint, there is no difference with regard to nation or state in terms of culture; culture is worldly. Modern China's failures in its confrontations with the West indicate that although Chinese culture is in the same space as Western culture, it belongs to an ancient time. Hence, it should be abandoned. This is the spirit in which Chen Duxiu published "Frenchmen and modern civilization" in New Youth, saying, "The civilizations of China and India sound modern but are in fact like relics from ancient times. Modern civilization is only owned by Europeans, that is, 
Western civilization".7 Hu Shi, a co-advocate with Chen Duxiu of the "New Culture Movement", warned, "If we still want to rectify this state, if we still hope that this nation take a stand in the world--there is only one way out, that is, we admit of our own faults: we must confess that we are inferior to others in every aspect, namely, we are inferior on material machineries and political systems, and, what's more, we are inferior on morality, literature, music, art and physical health". ${ }^{8}$ Another cultural radical, Chen Xujing, contended, "(1) European modern culture is really more advanced than ours. (2) Whether we like it or not, Western modern culture is where contemporary world is heading toward". ${ }^{9}$ This statement indicates that from the perspective of radicals, there is only a difference between advanced and backward cultures, but no difference in the type of culture. Radicals adopted critical and negative attitudes with respect to issues of traditional culture and maintained a high-degree identity toward Western culture and value. The original intention of Chinese radical nationalism, the attempt to construct a new China with the West as the blueprint, cannot be negated. When traditional national culture was incapable of effectively dealing with Western challenges or offering a sense of identity to its country men, the strong mentality of striving for prosperity and powerfulness drove them to adopt, resolutely and determinedly, the attitude of "bringing-ism", converting from the self to the other.

\section{Conclusion}

23 We can see from the analyses above that modern Sino-Western communication was conducted under unequal conditions. Chinese modernization is extrinsic and forced. During this modernization, Western developed countries, backed by their own economic and military strength, intended to forcefully import China into their "center-periphery" setup. This type of communication has been stamped by West-centralism. The backward conditions of underdeveloped nations in terms of economy, politics and military affairs present a predicament: on the one hand, to stand out in the world, China must seek modernity; on the other hand, to maintain the independent traits of the nation, it must criticize the modernity that suggests West-centralism. Modern China has a conflicted relationship with the globalization dominated by Western countries as well as with its own cultural tradition. This two-fold predicament, with conflict between self and the other, on the one hand, and tradition and modernity, on the other, has contributed to the formation of the ambivalence of modern Chinese national-cultural identity.

Internal and external difficulties forced Chinese radical nationalism to take a strong stand and to adopt extreme positions toward problems related to tradition. Particular historical circumstances led modern Chinese nationalism to include too many utilitarian purposes to have the time for profound reflections on deep-level issues of cultural value. Consequently, reflections on the level of value failed to fully enter the scope of consideration. At a surface level, this behavior, which approximated "shock therapy" in its complete abandonment of culture in the use of Western things to resist the West, was effective. This simple type of "bringing-ism", however, has ignored the complexity of cultural ideas and the construction of national identity. In fact, culture is more than simply material modality and systems; it involves more 
complicated issues pertaining to the idea of value. Cultural concepts of value at a deep level are not established overnight and will not be abandoned in a single day.

Conservative nationalism has lost the drive to self-criticize due to its overemphasis on its cultural superiority. Constantly emphasizing the particularity and superiority of the cultural value of one's own nation to dispel general cultural values and standards cannot effectively resolve the internal conflict between nationalization and globalization, nor can it resolve the predicament of modern Chinese national identity. The challenges with which China has been confronted since modern times indicate that China must perform conscientious self-criticism with regard to the shortages in its own culture and must abandon incorrect or absurd elements. Without such determination and courage, modernization will be difficult to accomplish in the true sense of the word.

The fact that globalization is a historical tendency in the development of human history demands that we should not adopt a blindly resistant attitude toward modernity originating from the West. "When stressing and defending a country's cultural, religious or linguistic harmony, nationalism should admit of diversity and pluralism, and of the plural cultures, diversified living styles and languages, among others, within a country."10 At the same time, when nationalism promotes its own national particularity, it should remain open to bravely admitting the reasonable factors of heterogeneous cultures. After suffering humiliation in modern times, China must accelerate the progression of modernization rather than clinging to tradition. As a state with a long history, however, it cannot and should not completely follow the West. The means of maintaining a proper balance is an issue of practice that goes beyond the replicability of pure theories.

\section{Notes}

1 Hegel, Phenomenology of Spirit, Oxford University Press, 1977, p.115.

2 Interpretations of Liji, Zhonghua Book Company, 2001, p.3.

3 Shen Jianmin, "The ideological trend of nationalism in late Qing Dynasty and modern Chinese national identity", The Journal of Humanities, 6, 2001.

4 Gu Hongming, The Spirit of Chinese People, Shanxin Normal University press, 2006, p.14.

5 Liang Qichao, Records of Thinkings and Viewings in Europe, in The Complete Works of Liang Qichao, Beijing Publishing House, 1999, p.2987.

6 Ai Kai, World-wide Ideological Trend of Anti-modernization, Guizhou People's Publishing House, 1999, p.225.

7 Chen Duxiu, "Frenchmen and modern civilization", Journal of Youth, Vol.1, No.1, $15^{\text {th }}$ September, 1915.

$8 \mathrm{Hu}$ Shi, "Introduction to my own thoughts", in The Anthology of Hu Shi's Philosophical Materials (Part A), East China Normal University Press, 1981, p.345.

9 Chen Xujing, "The outlet of Chinese Culture", in Academic Works of Chen Xujing, Sun Yat-sen University Press, 2004, p.8.

10 Cheng Xiao. Patriotism, nationalism and modernization--Interview with Prof. Viroli in Public Reason and Modern Learnings, SDX Joint Publishing Company, 2000, p.177. 


\title{
Pour citer cet article
}

Référence électronique

Yujun WU, « Modern Chinese National-Cultural Identity in the Context of

Globalization », Transtext(e)s Transcultures 跨文本跨文化 [En ligne], 7 | 2012, mis en

ligne le 02 décembre 2012, consulté le 27 mars 2013. URL :

http://transtexts.revues.org/456

\begin{abstract}
Auteur
Yujun WU

WU Yujun, Associate Professor at the Research Center of Value \& Culture at Beijing Normal University, studies political philosophy and has published two monographs: Uncertainty and Modern Humankinds' Existence (2011) and The Question of Identity in the Context of Modernity (2012).

WU Yujun est maître de conférences au Research Center of Value \& Culture à

I'Université Normale de Pékin. II travaille sur la philosophie politique et a publié notamment les livres Uncertainty and Modern Humankinds' Existence (2011) et The Question of Identity in the Context of Modernity (2012).
\end{abstract}

\section{Droits d'auteur}

(C) Tous droits réservés 